\title{
Kompleks Ratu Boko: Latar Belakang Pemilihan Tempat Pembangunannya
}

nfn. Kusen

Keywords: spatial, site location preference, Hindu-Buddha, temple, classic

\section{How to Cite:}

Kusen, nfn. Kompleks Ratu Boko: Latar Belakang Pemilihan Tempat $\begin{array}{lll}\text { Pembangunannya. Berkala 128-132. } & \text { Arkeologi, 15(3), }\end{array}$ https://doi.org/10.30883/jba.v15i3.684

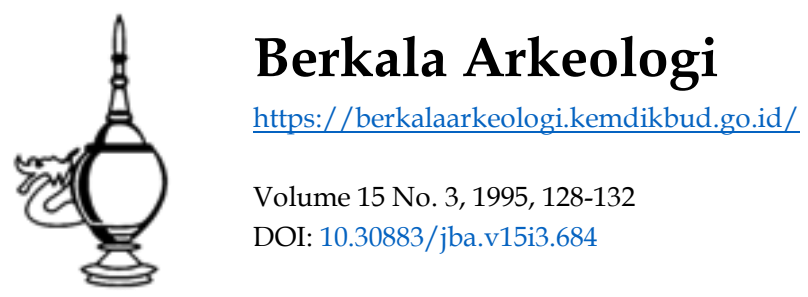

\section{(c) (1)(2)}

This work is licensed under a Creative Commons Attribution-NonCommercialShareAlike 4.0 International License. 


\title{
KOMPLEKS RATU BOKO: LATAR BELAKANG PEMILIHAN TEMPAT PEMBANGUNANNYA
}

\author{
Kusen \\ (Jurusan Arkeologi FS-UGM)
}

\section{Masalah}

Di dalam disertasinya yang berjudul Pertimbangan Ekologi dalam Penempatan Situs Masa Hindu-Buda di Daerah Yogyakarta: Kajian Arkeologi-Ruang Skala Makro, Mundardjito mengelompokkan situs-situs di daerah Yogyakarta menjadi empat kelompok. Pengelompokan ini didasarkan pada nilai-nilai variabel sumber daya lingkungannya (Mundardjito, 1993:203-212) Situssitus yang termasuk dalam kelompok I (Ratu Boko, Sumberwatu, Candi Dawangsari, Candi Barong. Candi Miri, Gupolo, Klengkong, Candi ljo, Ledoksari, Candi Tinjon) berada di lokasi yang potensi variabel sumberdaya lingkungannya paling rendah dibandingkan ketiga kelompok lainnya. Dari sembilan variabel sumberdaya lingkungan (ketinggian tempat, kelerengan, bentuk lahan, jenis tanah, batuan, kemampuan tanah, air tanah, jarak situs ke sungai, dan jarak situs ke sumber air) kelompok I hanya memiliki dua variabel berpotensi tinggi (ketinggian tempat dan jarak situs ke sungai) sedangkan variabel lainnya cenderung berpotensi rendah (lbid:231-232).

Selain hal tersebut di atas, dalam disertasinya, Mundardjito juga telah membahas tentang syarat-syarat dan prosedur pemilihan tempat untuk bangunan suci di india menurut kitab Mánasára-Silpasástra dan Silpa Prakasa. Uraian tentang pemilihan tempat untuk bangunan suci dalam kedua kitab tersebut dapat dikaitkan dengan potensi sumberdaya lingkungan fisik di calon lokasi bangunan bersangkutan. Selanjutnya disimpulkan bahwa pertimbangan ekologi dalam penempatan situs-situs di daerah penelitian pada dasarnya sesuai dengan prinsip yang termuat dalam kedua kitab India Kuno tersebut. Namun demikian, kesesuaian ini tidak sepenuhnya berlaku, sebab ada sebagian kecil situs yang tidak ditempatkan pada lahan berpotensi tinggi seperti ditunjukkan oleh situs-situs yang termasuk dalam kelompok I. Kenyataan ini menimbulkan pertanyaan besar yang menurut Mundardjito mungkin ada baiknya tidak dijawab melalui penelitian dengan model pendekatan ekologi. Akhirnya dikemukakan bahwa masalah tersebut dapat ditelaah lebih lanjut dengan cara pandang lain (Ibid:238-250).

"Tantangan" Mundardjito akan penulis tanggapi dalam makalah ini melalui analisis data sejarah-arkeologi dan analisis mengenai bentuk adaptasi terhadap fingkungan fisik. Untuk itu te-lah dipilih Kompleks Ratu Boko sebagai contoh kasus dengan pertimbangan sebagai berikut: Pertama, data sejarah mengenai situs Ratu Boko cukup memadai sehingga analisis kesejarahan dapat dilakukan. Kedua, pembatasan pengamat-an dalam skala keruangan meso (terbatas pada sebuah situs) memungkinkan dilakukannya deskripsi dan analisis data arkeologi secara lebih seksama. Hasil analisis diharapkan dapat menjawab pertanyaan mengapa para pembangun Kompleks Ratu Boko membangun kompleks di lokasi yang potensi sumberdaya alamnya rendah.

\section{Latar Belakang Sejarah, Fungsi Situs dan Bentuk Adaptasi Lingkungan}

Selama terlibat dalam penyusunan Rencana Induk Pengembangan Pariwisata Kawasan Boko tahun 1992 dan penyusunan Studi Kelayakan Pengembangan Kawasan Ratu Boko tahun 1994/ 1995, penulis telah mengumpulkan dan menganalisis berbagai data sejarah-arkeologi mengenai situs Ratu Boko. Dalam makalah singkat ini semua yang dipaparkan dalam kedua laporan kegiatan tersebut tidak mungkin diuraikan. Oleh karena itu apa yang akan dikemukakan hanya terbatas pada ringkasan hasil analisis dan interpretasinya.

Berdasarkan analisis dan interpretasi data prasasti, bangunan dan artefak lain yang ditemukan di kawasan Ratu Boko, dapat ditarik beberapa kesimpulan tentang latar belakang sejarah dan fungsi kompleks Ratu Boko sebagai berikut.

1) Kompleks Ratu Boko semula merupakan sebuah wihara yang bemama Abhayagiri. Pembangunan wihara ini dilakukan oleh Rakai Panangkaran antara tahun 784-792 M. Fungsi situs sebagai wihara ditunjukkan oleh adanya batur-batur bangunan rumah dan temuan lain yang berlatarbelakang agama Buddha seperti arca Buddha, reruntuhan stupa, stupika serta lempengan emas dan perak yang bertulisan mantera agama Buddha.

2) Pada sekitar tahun $856 \mathrm{M}$ fungsi kompleks Ratu Boko berubah menjadi kraton dari seo-rang penguasa daerah bernama Rakai Wa-laing Pu Kumbhayoni yang menganut agama Hindu. Nama tokoh ini masih disebut dalam prasasti Pereng tahun $863 \mathrm{M}$. Bukti adanya perubahan 
fungsi situs antara lain berupa te-muan yoni, tiga miniatur candi, arca Ganesa dan Durgamahisåsuramardini serta lempeng-an emas bertulisan mantera Hindu. Pada ma-sa ini Kawasan Ratu Boko disebut dengan na-ma Walaing.

3) Pada tahun $907 \mathrm{M}$, Walaing sebagai nama tempat disebut dalam prasasti Mantyasih yang dikeluarkan oleh raja Balitung. Dalam prasasti ini disebutkan bahwa penulis pra- sasti adalah Pu Tarka yang berasal dari Wa-laing. Dengan demikian setidak-tidaknya sam-pai awal abad $X$ kawasan Ratu Boko masih menjadi pemukiman penting.

Selanjutnya berdasarkan analisis data lingkungan dan unsur-unsur bangunan dapat diperoleh gambaran sebagai berikut. Kompleks Ratu Boko berada di atas perbukitan batu yang miskin sumber air. Para pembangun kompleks di masa lampau telah menunjukkan kemampuan beradaptasi dengan kondisi lingkungan setempat. Bukit-bukit batu dipangkas, permukaan tanah yang rendah ditimbun, halaman-halaman dibuat berteras-teras dengan talud dan pagar batu yang kokoh. Air hujan sebagai satu-satunya sumber air yang potensial ditampung dalam kolam-kolam buatan dan kelebihannya dikendalikan pembuangannya dengan sistem drainage yang sekaligus berfungsi sebagai cara konservasi air tanah. Tiang-tiang bangunan rumah didirikan di atas umpak-umpak batu baik yang terletak di atas batur maupun di atas tanah untuk menghindari kelembaban tanah.

\section{Pembahasan}

Prasasti-prasasti Jawa Kuno banyak yang menyebut tentang adanya sawah. Dari sini dapat diketahui bahwa masyarakat Jawa Kuno adalah masyarakat agraris. Sebagai masyarakat yang kehidupannya bersandar pada produk pertanian, mereka tentu memilih lingkungan yang subur sebagai tempat hunian mereka. Desa tempat ting-gal mereka disebut dengan istilah wanua. Selanjutnya beberapa wanua berada di dalam satuan wilayah administratif yang lebih besar yang disebut watak.

Berdasarkan 11 buah prasasti abad IX - X M yang ditemukan di Prambanan dan sekitarnya, penulis berhasil mendata adanya 69 nama watak dan 175 nama wanua. Meskipun tidak semua nama tempat yang disebut dalam prasasti terletak di Prambanan dan sekitarnya, namun dapat dipastikan bahwa pada masa itu Prambanan dan sekitarnya telah menjadi kawasan pemukiman yang cukup padat (Kusen, 1991a). Selain itu, banyaknya candi yang terdapat di kawasan ini se- cara tidak langsung juga dapat dipakai sebagai petunjuk bahwa dahulu kawasan ini memang merupakan daerah yang cukup padat penduduknya. Sebab, pembangunan candi apalagi candicandi yang besar seperti Candi Sewu, Plaosan dan candi Prambanan tentu memerlukan tenaga kerja yang cukup banyak. Padatnya pemukiman menunjukkan bahwa Prambanan dan sekitamya dahulu merupakan kawasan subur yang cocok untuk dihuni oleh masyarakat agraris.

Tingginya potensi sumberdaya lingkungan sejumlah situs di kawasan dataran Prambanan juga dibuktikan oleh Mundardjito melalui model pendekatan ekologi. Situs-situs tersebut dalam klasifikasi berdasarkan potensi sembilan variabel sumberdaya lingkungan termasuk dalam kelompok IV yaitu kelompok situs yang potensinya paling tinggi (Mundardjito, 1993:213 dan 231-232).

Dalam masyarakat Jawa Kuno, raja dan para penguasa daerah (rakai) mempunyai tiga hak istimewa yaitu drawya haji, gawai haji dan anugraha. Drawya haji adalah hak untuk memungut sebagian dari hasil produksi rakyatnya, gawai haji adalah hak untuk mengerahkan tenaga rakyat dan anugraha adalah wewenang untuk memberi-kan anugerah kepada mereka yang dianggap berjasa (Naerssen, 1977:41-43).

Hak pertama yaitu drawya haji menempatkan raja dan para penguasa daerah sebagai kelompok konsumen. Sebagai konsumen yang memiliki hak istimewa, mereka tidak perlu secara langsung menggarap tanah untuk memproduksi sendiri bahan makanan yang mereka perlukan. Dengan demikian lokasi "kraton", tempat penguasa bermukim, tidak harus berada di lahan yang subur. Hal terpenting "kraton" setidak-tidaknya terletak di lokasi yang mudah dijangkau (tingkat aksesibilitasnya tinggi) dan tidak jauh dari kawasan yang subur serta padat penduduknya. Ketiga hal ini antara lain sangat diperlukan untuk memberi kemudahan bagi penguasa menjalankan hak drawya haji dan gawai hajinya.

Kompleks Ratu Boko meskipun terletak di atas bukit yang potensi sumberdaya lingkungannya rendah, namun ditinjau dari segi keletakannya memiliki tingkat aksesibilitas yang cukup tinggi dan relatif dekat dengan area yang subur serta padat penduduknya. Faktor aksesibilitas yang cukup tinggi dan letaknya yang relatif dekat dengan area yang subur serta padat penduduknya inilah yang kemungkinan dipertimbangkan oleh Rakai Panangkaran ketika membangun wihara di atas bukit Ratu Boko. Sebab, seperti diketahui, kehidupan para bhiksu penghuni wihara memerlukan dukungan umat Buddha. Dukungan ini dapat diperoleh dengan mudah jika lokasi wihara tidak jauh dari pemukiman penduduk. Se- 
lanjutnya para bhiksu memerlukan tempat yang tenang untuk menjalani kehidupan keagamaan mereka. Suasana tenang dapat diperoleh di atas bukit karena perbedaan ketinggian tempat merupakan pembatas alami yang memisahkan wihara dari hiruk pikuk pemukiman di dataran sekitar bukit. Dalam hal ini pemberian nama Abhayagiriwihara yang artinya "wihara di bukit yang tidak berbahaya" mungkin berkaitan dengan suasana tenang dan damai yang dapat dirasakan di atas bukit. Selain itu lokasi wihara di atas bukit Ratu Boko tidak jauh dari candi Kalasan dan Sewu yaitu dua buah candi berlatar belakang agama Buddha yang juga didirikan oleh Rakai Panangkaran.

Kendala yang dihadapi dalam pembangunan Abhayagiriwihara di atas bukit adalah bentuk lahannya yang tidak rata dan tidak adanya sumber air potensial di lokasi bersangkutan. Kedua kendala ini dapat diatasi dengan menerapkan teknologi bangunan serta sistem pemanfaatan dan pengendalian air hujan sebagai berikut.

Permukaan bukit batu yang tidak rata dibentuk menjadi teras-teras halaman dengan teknik pemangkasan dan penimbunan (cut and fill). Untuk menahan tanah urug dari bahaya longsor atau erosi telah dibangun talud-talud yang kokoh. $\mathrm{Di}$ atas teras-teras halaman ini kemudian didirikan bangunan baik yang berfungsi sebagai rumah tinggal maupun yang berfungsi sebagai sarana keagamaan.

Air hujan ditampung dalam kolam-kolam yang dibuat dengan cara memahat batuan induk (bedrock). Air hujan dalam kolam tidak mudah susut karena tingkat permeabilitas batuannya rendah. Kolam-kolam ada yang dibuat di permukaan batuan yang berbeda ketinggiaannya (contohnya adalah kolam-kolam di kompleks Penda-pa dan Keputren). Perbedaan ketinggian kolam memungkinkan air yang tertampung dalam kolam atas meresap ke arah kolam yang berada di lereng bawahnya. Air resapan ini merupakan air bersih karena telah melalui lapisan batuan yang berfungsi sebagai filter. Kelebihan air dibuang melalui saluran-saluran pembuangan dan sistem peresapan. Dengan cara ini kebutuhan air untuk keperiuan sehari-hari dan untuk upacara keagamaan dapat terpenuhi. Dalam musim kemarau panjang, pada saat persediaan air menyusut, kebutuhan air dapat dipenuhi dengan cara mengambil air sungai Opak atau dari sumur-sumur yang terdapat di lembah sekitar bukit. Pembangunan kompleks wihara yang luas di atas bukit tentu memerlukan tenaga kerja dalam jumlah besar. Hal ini bukan merupakan masalah karena dalam membangun wihara Rakai Panangkaran dibantu oleh Rakai Panaraban yang pada saat itu menjabat sebagai raja Mataram Kuno. Dengan menggunakan hak gawai hajinya mereka dapat mengerahkan tenaga rakyat yang bermukim di lembah sekitar bukit.

Sebagai tambahan perlu dikemukan bahwa baru-baru ini penulis bersama Bambang Prasetyo, telah menemukan data arkeologi di atas bu-kit sebelah barat kompleks Ratu Boko. Data ter-sebut berupa jalan kuno, sejumlah kolam-kolam penampungan air, pecahan-pecahan keramik dan lubang-lubang di atas batuan induk yang diduga merupakan bekas kedudukan tiang ba-ngunan kayu atau bambu. Jalan kuno yang le-barnya 2,53 meter dan panjangnya \pm 300 meter, dibuat dengan cara memahat batuan induk. Ja-lan di punggungan bukit tersebut memanjang dari timur ke barat, kemudian membelok ke barat da-ya dan berakhir pada suatu dataran seluas $\pm 14 \mathrm{~m} \times 9 \mathrm{~m}$. Dataran ini sebagian berupa batuan in-duk dan sebagian berupa urugan batu dan tanah yang ditahan talud yang terbuat dari tatanan batu putih. Di sebelah selatan dataran terdapat tiga te-ras memanjang yang dibatasi dan diperkuat de-ngan talud. Di teras kedua terdapat kolam berpenampang lingkaran dengan garis tengah 1,5 meter. Selanjutnya di sepanjang sisi selatan dan timur jalan terdapat sejumlah kolam penampungan air hujan yang kini tertutup tanah dan dimanfaatkan oleh penduduk sebagai lahan pertanian. Di beberapa tempat yang berdekatan dengan kolam terdapat lubang-lubang kecil (garis tengah $10-20 \mathrm{~cm}$ ) yang terpahat di atas batuan induk. Ada lubang-lubang kecil pada sebuah dataran yang letaknya berkelompok membentuk denah empat persegi panjang. Hal ini memberi kesan bahwa lubang-lubang tersebut dahulu berfungsi sebagai tempat kedudukan tiang-tiang bangunan rumah sederhana yang terbuat dari kayu atau bambu. Selain itu, di atas bukit juga ditemukan pecahan-pecahan keramik yang di antaranya terdapat keramik Cina dari masa dinasti T'ang abad VIII-IX M. Jenis-jenis temuan tersebut menunjukkan bahwa dahulu situs berfungsi sebaga pemukiman.

Penemuan data pemukiman kuno di bukit barat Ratu Boko menimbulkan masalah sebagai berikut. $D i$ lembah sekitar bukit tersedia lahan yang ditinjau dari berbagai segi jauh lebih sesuai untuk dipakai sebagai pemukiman dibandingkan lahan di atas bukit. Dengan demikian faktor apa yang menyebabkan mereka memilih bermukim di atas bukit? Apabila pemukiman itu dahulu menjadi bagian dari Abhayagiriwihara penyebabnya sudah jelas seperti yang telah dipaparkan di depan. Namun apabila pemukiman itu bukan ba-gian wihara, maka faktor penyebabnya masih ha-rus dicari. 
Daiam makalah singkat ini penulis hanya sekedar mengajukan gagasan spekulatif yang kebenarannya perlu dibuktikan di masa mendatang. Adapun gagasan tersebut adalah sebagai berikut. Pembangunan pemukiman di bukit barat Ratu Boko disebabkan oleh adanya kerusakan lingkungan fisik yang luar biasa di Prambanan dan sekitarnya. Kerusakan lingkungan ini terjadi akibat banjir lahar dingin di masa lampau yang melanda hampir sebagian besar lereng dan dataran di selatan gunung Merapi. Adanya endapan lahar dingin yang cukup tebal sampai sekarang masih dapat disaksikan yaitu antara lain di Candi Sambisari ( $\pm 8,5$ meter), Candi Kedulan ( \pm 4 meter), Candi Sewu ( \pm 1,5 meter), Candi Plaosan ( $\pm 2,5$ meter) dan situs Wonoboyo ( \pm 3 meter). Banjir lahar dingin tersebut telah menghancurkan sebagian besar lahan pertanian, pemukiman dan kompleks percandian di kawasan ini serta memaksa penduduk setempat untuk mengungsi. Salah satu tempat pengungsian yang bebas dari jangkauan lahar dingin adalah daerah perbukitan di selatan Prambanan, termasuk bukit Ratu Bo-ko. Melihat tebalnya lapisan lahar dingin, dapat diduga bahwa kerusakan lingkungan yang terjadi sangat luar biasa. Hal ini mengakibatkan pengungsian penduduk berlangsung cukup lama dan mungkin sampai hitungan tahun. Penduduk yang mengungsi kemudian mendirikan pemukim-an sementara di atas perbukitan sambil menung-gu kesempatan untuk kembali bermukim di dae-rah dataran.

Menarik perhatian bahwa di kawasan perbukitan mulai dari Ratu Boko sampai ke candi ljo ditemukan peninggalan yang menunjukkan unsur-unsur pemujaan terhadap Wisnu. Peninggalan tersebut antara lain candi Barong, arca Balarama, arca Narasimha dan arca Triwikrama. Seperti diketahui dalam agama Hindu, Wisnu berkedudukan sebagai dewa penolong dan pemelihara. Oleh karena itu dapat dipersoalkan ada tidaknya hubungan antara munculnya pemujaan Wisnu dengan peristiwa bencana lahar dingin dan pengungsian penduduk ke daerah perbukit-an. Selain itu perlu dikaji pula kemungkinan ada-nya candi-candi di perbukitan yang dibangun oleh para pengungsi setelah candi-candi di dataran mengalami kerusakan dan untuk sementara atau seterusnya tidak dapat digunakan.

\section{Harapan Masa Depan}

Hingga saat ini, penerapan teknik-teknik pertanggalan mutlak (absolute dating atau chronometric dating) untuk data arkeologi belum banyak dilakukan di Indonesia. Akibatnya, banyak pertanyaan yang sebenarnya dapat dijawab "ya atau tidak" terpaksa dijawab dengan "mungkin"; perta- nyaan mengenai kapan sebuah artefak dibuat tidak dijawab dengan "tahun $X \pm n$ tahun", namun dijawab dengan "masa/periode $Y$ atau antara abad sekian sampai sekian". Dampak lainnya, banyak peristiwa masa lalu yang sebenarnya dapat direkonstruksi secara lebih cermat dan terinci dengan bantuan teknik-teknik pertanggal-an mutlak (termasuk masalah-masalah yang berkaitan dengan kapan bencana lahar dingin melanda kawasan Prambanan dan sekitarnya) tetap menjadi persoalan yang mengambang. Oleh karena itu sudah tiba saatnya bagi para ahli arkeologi untuk lebih sungguh-sungguh mengupayakan adanya dana bagi penerapan teknik-teknik pertanggalan mutlak dalam penelitian arkeologi. Dengan demikian "absolute dating" atau chronometric dating bukan hanya sekedar menjadi "mitos" tetapi kenyataan.

\section{KEPUSTAKAAN}

Bambang,Sumadio,(ed).1992. Sejarah Nasional Indonesia II Edisi IV Jakarta:Balai Pustaka

Casparis,JG. de. 1956. Prasasti Indonesia II, Bandung: Masa Baru.

Deparpostel Ditjen Pariwisata. 1992.Rencana Induk Pengembangan Pariwisata Kawasan Ratu Boko Prambanan Kabupaten Sleman. Yogyakarta, Laporan Antara, Jakarta:PT Agha Svedco.

Kanwil VIII Deparpostel DIY.1994. Studi Kelayak an Pengembangan Kawasan Ratu Boko Prambanan Laporan Kemajuan Amdal Yog-yakarta:PAU Studi Sosial UGM.

Kusen.1991a.Identifikasi Toponim dalam Prasasti Jawa Kuna Abad IX-X dari Pram-banan dan Sekitarnya dengan Toponim Masa Kini. Laporan Penelitian, Yogyakarta:FS-UGM.

1991b. The Gold Hoard of Wonoboyo: A Heritage of Ancient Mataram Kingdom. This paper was presented at the meeting of the Ceramics Society of Indonesia Jakarta on May 1, 1991.

1994. Raja-raja Mataram Kuna dan Sanjjaya sampai Balitung: Sebuah Rekonstruksi Berdasarkan Prasasti Wanua Tengah III. Makalah dalam Seminar Evaluasi Data dan interpretasi Baru Sejarah Indonesia Kuna, Yogyakarta: Balai Arkeologi. 
Maria Tri Widayati. 1994. Sistem Pengelolaan Air di Kompleks Kraton Ratu Boko, Skripsi Sarjana Arkeologi, Yogyakarta: FS-UGM.

Mundardjito. 1993. Pertimbangan Ekologi dalam Penempatan Situs Masa Hindu-Budha di Daerah Yogyakarta:Kajian Arkeologi-Ruang Skala Makro, Disertasi, Jakarta:UI.
Naerssen, FH. van. 1977. The Economic and Administrative History of Early Indonesia Leiden: E.J. Brill. 